\section{Food security status in times of financial and political crisis in Brazil}

\author{
A segurança alimentar em tempos de crise \\ financeira e política no Brasil
}

\section{Estado de la seguridad alimentaria en la era de la crisis política y financiera brasileña}

Luna Rezende Machado de Sousa 1

Ana Maria Segall-Corrêa 2

Arlette Saint Ville 1

Hugo Melgar-Quiñonez

\begin{abstract}
This study sought to describe the changes in the food security status in Brazil before and during its most recent financial and political crisis, as well as to explore associations between food security and socioeconomic factors during the crisis. This cross-sectional study analyzed data from two different sources: the Brazilian National Household Sample Survey for $2004(n=112,479)$, 2009 ( $n=120,910)$, and $2013(n=116,192)$; and the Gallup World Poll for 2015 ( $n=1,004), 2016(n=1,002)$, and $2017(n=1,001)$. Household food security status was measured by a shorter version of the Brazilian Food Insecurity Scale, consisting of the first 8 questions of the original 14-item scale. Descriptive and logistic regression analyses were performed to assess the changes in food security and their association with socioeconomic factors. Results suggest that during the crisis the percentage of households classified as food secure declined by one third (76\% in 2013 to 49\% in 2017) while severe food insecurity tripled (4\% in 2013 to 12\% in 2017). Whereas before the crisis (2013) 44\% of the poorest households were food secure, by 2017 this decreased to 26\%. Household income per capita was strongly associated with food security, increasing by six times the chances of being food insecure among the poorest strata. Those who reported a low job climate, social support or level of education were twice as likely to be food insecure. Despite significant improvements between 2004 and 2013, findings indicate that during the crisis Brazil suffered from a great deterioration of food security, highlighting the need for emergency policies to protect and guarantee access to food for the most vulnerable.
\end{abstract}

Food and Nutrition Security; Nutritional Epidemiology;

Socioeconomic Factors

\author{
Correspondence \\ L. R. M. Sousa \\ McGill University. \\ 140, Boulevard Thompson, Montreal / Quebec - H4N1B7, \\ Canada. \\ luna.rezendemachadodesousa@mail.mcgill.ca \\ 1 McGill University, Montreal, Canada. \\ 2 Faculdade de Ciências Médicas, Universidade Estadual de \\ Campinas, Campinas, Brasil.
}




\section{Introduction}

Food security, defined as the stable access to adequate food, is directly affected by economic factors, such as stagnating growth, high food prices, low income, and unemployment 1,2,3,4,5. Additionally, as political environments influence the stability of food economies and governmental commitments towards food security policies, political crises are negatively correlated with food security 6 . Therefore, in order to improve food access and guarantee the Right to Food, food security policies should address these issues by raising income, managing risks of economic shocks and strengthening national institutions $1,6,7,8$.

Regarding successful food security policies, Brazil has been known worldwide for reducing food insecurity by improving food access, income generation, supporting the food production by small farmers, and enhancing food security governance including civil society organizations 9,10,11. Most importantly, alongside these developments, Brazil built a robust legal and institutional framework for food security, transforming the fight against hunger into a state obligation 6,12,13,14. These political and social commitments were established in a period marked by strong economic growth and reduction of unemployment 15 . As a result, poverty and severe food insecurity were drastically reduced from 2004 to 2014 in Brazil 10,16,17,18,19.

It is understood that economic prosperity bolsters food security, and in contrast economic and political shocks undermine such gains 4,7,17,20,21,22,23,24,25. Recently, the Food and Agriculture Organization of the United Nations (FAO) reported that undernourishment at a global level, after years of decline, increased from 2015 to 2016 due to the economic and political crises that occurred in many developing countries ${ }^{8}$. The impact of economic downturns on food security suggests a threat to food security in Brazil, as since 2014 the country faces a major economic crisis along with political instability 26,27,28. As a result, in 2016 there was a presidential impeachment in Brazil, which along with many revelations of corruption compromised the political stability of the country 10,27 . This crisis lead to the worsening of many social indicators, such as income and unemployment, which affected $12 \%$ of the population in 2016 15,26,27. Inflation led to increases in national food prices, mostly affecting staple foods (rice, beans), vegetables, fruits and meat 15,29. As a result, the Brazilian government responded with austerity measures, which led to reduced funding for many social and food security policies 26,28,30,31. Moreover, long term projections are not optimistic, with leading economists forecasting economic recovery only after 202028 .

Although financial and political crises having a negative impact on food security is consensus in academia 2,32,33, current studies provide snapshots rather than continuous assessments of food security status in affected countries 4,7,21,25,34. In the case of Brazil, there are still no studies on the effects of this crisis on national food security status. As timely food security measurements are needed to inform policy, this study aims to fill both gaps and contribute to the discussion on how food security can be affected by economic and political instability even in countries where there is a strong social policy framework. Thus, our first objective is to describe the changes in food security status in Brazil before (from 2004 to 2013) and during the crisis (from 2015 to 2017). The second objective is to explore associations between food security and socioeconomic factors during the crisis.

\section{Materials and methods}

\section{Data sources}

To describe the changes in food security status before and during the economic and political crisis in Brazil, this study used national data from two different sources. Data from the period before the crisis came from the Brazilian National Household Sample Survey (PNAD), which assessed food security status in $2004(\mathrm{n}=112,479), 2009(\mathrm{n}=120,910)$ and $2013(\mathrm{n}=116,192)$. Data collected during the crisis came from the Gallup World Poll (GWP), which assessed food security in Brazil in 2015 ( $\mathrm{n}=1,004), 2016$ $(\mathrm{n}=1,002)$ and $2017(\mathrm{n}=1,001)$. These two data sources were used to complement each other. This approach was necessary because there is no single data source available that provides national data on food security in Brazil for both periods, before and during the crisis. In order to explore associations 
between food security and socioeconomic factors during the crisis, only data from the GWP were utilized, as it covered the last three most recent years of the crisis: 2015, 2016 and 2017.

The PNAD, conducted annually by the Brazilian Institute of Geography and Statistics (IBGE), is a population-based epidemiological survey that collects sociodemographic information on an average sample of over 110,000 households 19. Special supplements that investigate other characteristics of the population are added to the PNAD with a variable periodicity, such as food security assessments which were included in 2004, 2009 and 201319.

The GWP, created in 2005, is a survey conducted annually in more than 140 countries on an average sample of 1,000 households per country, which is designed to ensure national representativeness 35 . This research is rich in opinion and perception measurements, and also includes questions on sociodemographic factors. Since 2014, in collaboration with the FAO, GWP has included a global assessment of food security in the survey 35,36 .

Both surveys, PNAD and GWP, cover the entire country, including rural areas, and provide a nationally representative sample 19,35. Regarding their sampling methods, both surveys applied a multiple cluster design to randomly select their samples in three stages: municipalities, census tracts, and households 19,35. As GWP collects smaller samples compared to national surveys, after collection the data are weighed by gender, age, education and socioeconomic status to match the national demographics 35 . All interviews from PNAD and GWP were conducted face to face with one individual over 15 years old in each household 19,35 .

Food security status was measured by both data sources, PNAD and GWP, using the Brazilian Food Insecurity Scale (EBIA). EBIA is a national psychometric scale consisting of 14 questions related to the direct experience of food insecurity 19 . The first eight questions of EBIA are addressed to all households. The remaining six questions are only used in households with members less than 18 years of age 19. PNAD used the original EBIA to assess food security status, while the GWP applied the shorter version of EBIA (EBIA-8), which consists of the first 8 questions of the original scale.

In a recent study conducted by Interlenghi et al. 37 , EBIA- 8 was validated against the original 14-item scale, according to their level of agreement in the classification of household food security status. The authors concluded that results from EBIA-8 are reliable and consistent with the results from the original scale, and recommended the use of EBIA- 8 when it is not possible to apply the 14-item scale 37 . Due to the differences in how the EBIA was applied in Brazil by PNAD (14 questions) and GWP (8 questions), the household food security status measured by PNAD (in 2004, 2009 and 2013) was recalculated according to the EBIA- 8 with use of PNAD microdata. Thus, in this study, all the data on food security status is based on EBIA-8.

\section{Dependent variable}

Food security, as measured by EBIA-8, was used as the dependent variable. This scale measures the limited access to adequate food and resourses, using questions related to the quality, variety and amount of food, as well as hunger experiences such as skipping meals and not eating for an entire day because of the lack of resources 19,37. This scale (Table 1) has eight questions with "no" and "yes" responses 19,37. Each positive answer is assigned one point and the total score is used to classify the household food security status as follows: $0=$ food security; 1 to $3=$ mild food insecurity; 4 to $5=$ moderate food insecutiry; and 6 to $8=$ severe food insecurity 19,37 . EBIA- 8 is based on a household level assessment and the reference period of the questions covers three months prior to the interview 19,37.

\section{Independent variables}

A number of independent variables was utilized to explore the associations between food security status and socioeconomic factors during the crisis (GWP data), including: per capita household income; perception of political stability; household size; age; educational level; and gender of the respondent. Additionally, two GWP indices were used to measure job climate and social support 36 .

Household income per capita was analyzed in four strata based on the Brazilian minimum wage. The first stratum, which refers to people receiving up to $1 / 4$ of minimum wage, and the second stratum, people receiving from $1 / 4$ to $1 / 2$ of the minimum wage, are equivalent to the line of extreme poverty 
Table 1

Characteristics and questions of the short version of the Brazilian Food Insecurity Scale (EBIA-8).

\begin{tabular}{|c|c|}
\hline & Characteristics/Questions \\
\hline Level reference & Household level \\
\hline Time reference & 3 months prior \\
\hline Application & $\begin{array}{c}\text { In 2004, } 2009 \text { and } 2013 \text { by the Brazilian National Household Sample Survey (PNAD); in 2015, } 2016 \text { and } 2017 \text { by the } \\
\text { Gallup World Poll. }\end{array}$ \\
\hline \multirow[t]{8}{*}{ Questions } & $\begin{array}{l}\text { 1. During the past three months, were the residents of this household worried the food would run out before } \\
\text { they could buy or receive more food? }\end{array}$ \\
\hline & $\begin{array}{l}\text { 2. During the past three months, did the food run out before residents of the household were able to buy more } \\
\text { food? }\end{array}$ \\
\hline & 3. During the past three months, did residents of this household not have money for a healthy and varied diet? \\
\hline & $\begin{array}{l}\text { 4. During the past three months, did residents of this household eat only a few kinds of food that they still had in } \\
\text { the house because money ran out? }\end{array}$ \\
\hline & $\begin{array}{l}\text { 5. During the past three months, did any household member } 18 \text { years or older skip a meal because there was no } \\
\text { money to buy food? }\end{array}$ \\
\hline & $\begin{array}{l}\text { 6. During the past three months, did any household member } 18 \text { years or older eat less than they should have } \\
\text { because there was no money to buy food? }\end{array}$ \\
\hline & $\begin{array}{l}\text { 7. During the past three months, did any household member } 18 \text { years or older feel hungry and not eat because } \\
\text { there was no money to buy food? }\end{array}$ \\
\hline & $\begin{array}{l}\text { 8. During the past three months, did any household member } 18 \text { years or older eat only one meal a day or go an } \\
\qquad \text { entire day without eating, because there was no money to buy food? }\end{array}$ \\
\hline Food security status & Thresholds \\
\hline Food security & 0 \\
\hline Mild food insecurity & $1-3$ \\
\hline Moderate food insecurity & 4-5 \\
\hline Severe food insecurity & $6-8$ \\
\hline
\end{tabular}

Source: Brazilian Institute of Geography and Statistics (IBGE) 19.

and poverty in Brazil, respectively 18. Perception of political stability was measured using the question "How stable do you see the political situation in this country nowadays? (very stable, somehow stable, or not stable at all)" 36 . Household size was divided into three categories: " 1 to 3 ", "4 to 5" and "6 or more" residents. Age was analyzed in three subgroups: "youth (15 to 29 years)", "adult (30 to 59 years)", and "older people (60 years or more)". Educational level was also divided into three categories: "elementary or less", "secondary/high school" and "college/university". For gender, two categories were considered: "men" and "women".

Job climate was measured by the GWP Job Climate Index, which assesses people`s perceptions of job opportunities and the economic situation through the questions: "Thinking about the job situation in the city or area where you live today, would you say that it is now a good time or a bad time to find a job? (yes or no)"; "Right now, do you think that economic conditions in the city or area where you live, as a whole, are getting better or getting worse? (yes or no)" 36. Based on their answers, individuals are classified as having a "low", "moderate" or "high job climate" 36. This index, validated by the GWP, showed a good reliability and criterion validity, with a Cronbach's alpha of 0.85 and a significant association with GINI Index (Pearson's $r=0.41$ ) and long-term unemployment (Pearson's $\mathrm{r}=-0.54)$ at the country level 36 .

Social support was measured by the GWP Social Life Index. This index assesses perceived and integrative social support, respectively, using the following questions: "If you were in trouble, do you have relatives of friends you can count on to help you whenever you need them, or not? (yes or no)"; "In the city or area where you live, are you satisfied or dissatisfied with the opportunities to meet people and make friends? (yes or no)" 36,38. Individuals are classified as having "low", "moderate" or 
"high" social support ${ }^{36}$. This index, also validated by the GWP, showed a Cronbach's alpha of 0.65 and significant association with adult literacy rate (Pearson's $r=-0.58$ ) and life expectancy (Pearson's $\mathrm{r}=0.64)$ at the country level 36 .

\section{Data analysis}

Analyses were conducted separately for each period analyzed, before the economic and political crisis using data from PNAD (for the years 2004, 2009 and 2013) and during the crisis using data from GWP (years 2015 to 2017), seeking to describe the changes in food security status and household income per capita within each period. To evaluate if these changes were statistically significant ( $p$-value $\leq 0.05$ ) and to explore temporal associations within each period analyzed (before and during the crisis), z-tests adjusted by Bonferroni-correction and linear-by-linear association chi-squared tests were applied.

To explore the association between food security status and household income per capita, crosstabulation analyses were performed separately for each selected year (2004, 2009, 2013, 2015, 2016 and 2017), using z-test adjusted by Bonferroni-correction and linear-by-linear association chisquared tests.

Multiple logistic regression analysis was carried out to study the association between food security status and socioeconomic factors during the crisis (2015 to 2017) using data from the GWP. For regression analysis, EBIA- 8 was recoded into $0=$ food secure and $1=$ food insecurity. Statistical analyses were performed using the application software SPSS, version 23 (https://www.ibm.com/).

\section{Results}

Characteristics of the samples from 2004 to 2017 are presented in Table 2. From 2004 to 2013, before the economic and political shock, an increasing trend was observed for food security (63\% to $76 \%$ ). Nevertheless, the results indicate a large decline in food security during the crisis (76\% in 2013 to 49\% in 2017).

Regarding severe food insecurity, a decrease was found before the crisis between 2004 and 2013 (from 10\% to 4\%). However, severe food insecurity increased during the crisis from 2015 to 2017, reaching a prevalence of $12 \%$, which was higher than all previous assessments. Findings for household income per capita indicate that about $46 \%$ of the sample lived with more than 1 minimum wage between 2004 and 2013, which declined to 26\% in 2017. The opposite was observed for extreme poverty (less than $1 / 4$ minimum wage per capita), while before the crisis the proportion of households living in this condition was around 9\%, in 2017 it increased to $17 \%$.

Results from cross-tabulation analyses (Table 3) show significant associations ( $\mathrm{p}<0.001)$ between household income per capita and food security status from 2004 to 2017. In 2013, before the crisis, $44 \%$ of the poorest people were food secure, while in 2017 only $26 \%$ of the poorest were food secure.

Findings in Table 4 reveal that household income per capita had the highest association with food security status during the crisis. Households with no income and up to $1 / 4$ minimum wage per capita were six times more likely to be food insecure $(\mathrm{OR}=6.42 ; \mathrm{p}<0.001)$. Furthermore, those who reported low job climate $(\mathrm{OR}=1.84 ; \mathrm{p}<0.001)$, low social support $(\mathrm{OR}=2.37 ; \mathrm{p}=0.001)$ and had the lowest educational level $(\mathrm{OR}=2.24$; $\mathrm{p}<0.001)$ were on average two times more likely to be food insecure. Older people were $37 \%$ less likely to be food insecure $(\mathrm{OR}=0.63 ; \mathrm{p}=0.001)$.

\section{Discussion}

This study shows, for the first time to the best of our knowledge, a deterioration of food security in Brazil during its most recent financial and political crisis. As the literature lacks continuous monitoring of food security in times of economic and political instability, a gap in knowledge was filled by assessing the changes in food security status before $(2004,2009,2013)$ and throughout the current Brazilian crisis (2015 to 2017). 
Table 2

Changes in food security status and household income per capita before and during the crisis in Brazil.

\begin{tabular}{|c|c|c|c|c|c|}
\hline Period & Variables & $2004(\%)$ & $2009(\%)$ & $2013(\%)$ & $\begin{array}{l}\text { Linear-by-linear } \\
\text { association * }\end{array}$ \\
\hline \multirow[t]{10}{*}{ Before the crisis ** } & Household food security status & $n=112,479$ & $n=120,910$ & $n=116,192$ & $<0.001$ \\
\hline & Food secure & $63.3 a$ & $68.3 b$ & $76.3 c$ & \\
\hline & Mild food insecurity & $13.9 a$ & $16.1 b$ & $13.0 c$ & \\
\hline & Moderate food insecurity & $12.5^{a}$ & $8.5^{b}$ & $6.3 c$ & \\
\hline & Severe food insecurity & $10.3 a$ & $7.1 \mathrm{~b}$ & $4.4 c$ & \\
\hline & Household income per capita & $\mathrm{n}=110,116$ & $\mathrm{n}=117,579$ & $n=110,687$ & $<0.001$ \\
\hline & More than 1 minimum wage & $46.2^{a}$ & $44.9 \mathrm{~b}$ & $47.0 c$ & \\
\hline & $1 / 2$ to 1 minimum wage & $27.2^{\mathrm{a}}$ & $29.2^{b}$ & $29.3^{b}$ & \\
\hline & $1 / 4$ to $1 / 2$ minimum wage & $17.0 \mathrm{a}$ & $16.5 b$ & $15.3 c$ & \\
\hline & No income to $1 / 4$ minimum wage & $9.5 a$ & $9.4 a$ & $8.5 b$ & \\
\hline Period & Variables & $2015(\%)$ & $2016(\%)$ & $2017(\%)$ & $\begin{array}{l}\text { Linear-by-linear } \\
\text { association * }\end{array}$ \\
\hline \multirow[t]{10}{*}{ During the crisis $* \star \star$} & Household food security status & $\mathrm{n}=964$ & $\mathrm{n}=989$ & $\mathrm{n}=966$ & 0.012 \\
\hline & Food secure & $53.2 \mathrm{a}$ & $43.8 \mathrm{~b}$ & $48.6 \mathrm{a}, \mathrm{b}$ & \\
\hline & Mild food insecurity & $26.9 a$ & $32.7 b$ & $28.5 \mathrm{a}, \mathrm{b}$ & \\
\hline & Moderate food insecurity & $11.6 a$ & $12.3 a$ & $11.0 \mathrm{a}$ & \\
\hline & Severe food insecurity & $8.3 a$ & $11.2 \mathrm{a}, \mathrm{b}$ & $12.0^{b}$ & \\
\hline & Household income per capita & $\mathrm{n}=1,003$ & $\mathrm{n}=1,001$ & $\mathrm{n}=1,000$ & 0.023 \\
\hline & More than 1 minimum wage & $28.3 a$ & $24.1 \mathrm{a}$ & $26.3 a$ & \\
\hline & $1 / 2$ to 1 minimum wage & $35.1 \mathrm{a}$ & $32.5 a$ & $32.3 a$ & \\
\hline & $1 / 4$ to $1 / 2$ minimum wage & $23.3 a$ & $25.4 a$ & $24.5 a$ & \\
\hline & No income to $1 / 4$ minimum wage & $13.3^{a}$ & $18.1^{b}$ & $16.9 a, b$ & \\
\hline
\end{tabular}

Note: different superscripts denote statistically significant differences at a 0.05 level between column proportions within each period analyzed (before and during the crisis).

* Mantel-Haenszel linear-by-linear association chi-squared test p-value;

** Data source: Brazilian National Household Sample Survey;

*** Data source: Gallup World Poll.

While it is expected that economic and political crises would undermine food security gains, it has been widely assumed that a well-designed food security policy environment would protect the Right to Food of the most vulnerable and mitigate impact and extent of declines in food security status. However, amid austerity measures that have greatly reduced their funding 26,28,30,31, the successful Brazilian food security policies, recognized as a model for developing countries 1,2,6, were not enough to avoid a deterioration in food security in Brazil during the country's financial and political crisis. As seen in other countries without the robust food security institutional and policy arrangements of Brazil 4,24,34, the results suggest a major decline of food security during the crisis (from $76 \%$ in 2013 to $49 \%$ in 2017) and a 300\% increase of severe food insecurity (from $4 \%$ in 2013 to $12 \%$ in 2017).

To illustrate the magnitude of this decline in food security, in 2017 the prevalence of severe food insecurity (12\%) was $2 \%$ higher than that found 13 years before (10\%), when the most important food security policies started to be implemented in the country. In contrast, a study assessing food security status in Mexico before (2008) and after (2010) its economic downturn showed a lighter increase in severe food insecurity ( $8 \%$ to $10 \%$ ) but also in food security (57\% to 60\%) 21 . Nonetheless, it is difficult to compare these results with the Brazilian situation, as in Mexico the analysis focused on the period before and after the crisis, while in Brazil the crisis is still ongoing. Moreover, the economic downturn in Mexico lasted less than two years, and the country showed quick recovery in its GDP growth from 2009 (-4.7) to $2010(5.1) 15,21$. 
Table 3

Cross-tabulation analysis between household food security status and household income per capita in Brazil.

\begin{tabular}{|c|c|c|c|c|c|c|}
\hline \multirow[t]{2}{*}{ Period } & \multirow{2}{*}{$\begin{array}{l}\text { Household income per capita } \\
\text { (minimum wage) }\end{array}$} & \multicolumn{4}{|c|}{ Household food security status (\%) } & \multirow{2}{*}{$\begin{array}{l}\text { Linear-by-linear } \\
\text { association * }\end{array}$} \\
\hline & & $\begin{array}{l}\text { Food } \\
\text { secure }\end{array}$ & $\begin{array}{l}\text { Mild food } \\
\text { insecurity }\end{array}$ & $\begin{array}{l}\text { Moderate food } \\
\text { insecurity }\end{array}$ & $\begin{array}{l}\text { Severe food } \\
\text { insecurity }\end{array}$ & \\
\hline \multicolumn{7}{|c|}{ Before the crisis ** } \\
\hline 2004 & More than 1 & $85.0 \mathrm{a}$ & $9.1 \mathrm{~b}$ & $4.0 c$ & $2.0 d$ & $<0.001$ \\
\hline \multirow[t]{3}{*}{$n=110,116$} & $1 / 2$ to 1 & $58.9 a$ & $17.7 \mathrm{~b}$ & $15.0 c$ & $8.5^{d}$ & \\
\hline & $1 / 4$ to $1 / 2$ & $35.3^{a}$ & $20.4 b$ & $24.1 c$ & $20.2 c$ & \\
\hline & No income to $1 / 4$ & 18.9a & $15.5^{b}$ & $27.1 \mathrm{c}$ & $38.5^{d}$ & \\
\hline 2009 & More than 1 & $84.9 a$ & $11.1 \mathrm{~b}$ & $2.6 \mathrm{c}$ & $1.4^{d}$ & $<0.001$ \\
\hline \multirow[t]{3}{*}{$n=117,579$} & $1 / 2$ to 1 & $65.0 \mathrm{a}$ & $19.2^{b}$ & $9.6 c$ & $6.2^{\mathrm{d}}$ & \\
\hline & $1 / 4$ to $1 / 2$ & $47.5 a$ & $22.3 b$ & $16.4 c$ & $13.8 \mathrm{c}$ & \\
\hline & No income to $1 / 4$ & $33.1 \mathrm{a}$ & $19.8^{b}$ & $20.6 c$ & $26.5^{d}$ & \\
\hline 2013 & More than 1 & $89.5 a$ & $7.7 \mathrm{~b}$ & $1.9 \mathrm{c}$ & $1.0 \mathrm{~d}$ & $<0.001$ \\
\hline \multirow[t]{3}{*}{$n=110,687$} & $1 / 2$ to 1 & $73.4^{a}$ & $15.8^{b}$ & $6.9 c$ & $3.9 \mathrm{~d}$ & \\
\hline & $1 / 4$ to $1 / 2$ & $56.9 a$ & $20.8^{b}$ & $13.1 \mathrm{c}$ & $9.1 c$ & \\
\hline & No income to $1 / 4$ & $43.9 a$ & $20.6^{b}$ & $17.9 c$ & $17.5^{d}$ & \\
\hline \multicolumn{7}{|c|}{ During the crisis $* \star \star$} \\
\hline 2015 & More than 1 & $74.7 a$ & $18.9 \mathrm{~b}$ & $3.4 c$ & $3.0^{b, c}$ & $<0.001$ \\
\hline \multirow[t]{3}{*}{$n=964$} & $1 / 2$ to 1 & $58.4^{a}$ & $27.9 a, b$ & $7.9 c$ & $5.9 a, c$ & \\
\hline & $1 / 4$ to $1 / 2$ & $39.8^{a}$ & $32.5^{b}$ & $16.9 \mathrm{~b}$ & $10.8^{b}$ & \\
\hline & No income to $1 / 4$ & $18.9 a$ & $31.5^{b}$ & $29.1 c$ & $20.5 c$ & \\
\hline 2016 & More than 1 & $68.8^{a}$ & $23.8^{b}$ & $4.2^{b}$ & $3.3^{b}$ & $<0.001$ \\
\hline \multirow[t]{3}{*}{$\mathrm{n}=988$} & $1 / 2$ to 1 & $46.7 a$ & $37.4 a$ & $10.0 \mathrm{a}, \mathrm{c}$ & $5.9 \mathrm{~b}$ & \\
\hline & $1 / 4$ to $1 / 2$ & $32.7 a$ & $36.3^{b}$ & $15.7 \mathrm{~b}$ & $15.3^{b}$ & \\
\hline & No income to $1 / 4$ & $20.7 a$ & $31.8^{b}$ & $22.3 c$ & $25.1 c$ & \\
\hline 2017 & More than 1 & $68.5^{a}$ & $21.9 \mathrm{~b}$ & $4.6 c$ & $5.0 \mathrm{~b}$ & $<0.001$ \\
\hline \multirow[t]{3}{*}{$n=966$} & $1 / 2$ to 1 & $53.2^{a}$ & $32.6^{a}$ & $9.8^{a}$ & $4.4^{b}$ & \\
\hline & $1 / 4$ to $1 / 2$ & $34.9 a$ & $31.5^{b}$ & $16.6 \mathrm{~b}$ & $17.0 \mathrm{~b}$ & \\
\hline & No income to $1 / 4$ & $26.3^{a}$ & $26.9 \mathrm{~b}$ & $15.4 \mathrm{~b}$ & $31.4 c$ & \\
\hline
\end{tabular}

Note: different superscripts denote statistically significant differences at a 0.05 level between column proportions within each period analyzed (before and during the crisis).

* Mantel-Haenszel linear-by-linear association chi-squared test p-value;

** Data source: Brazilian National Household Sample Survey;

*** Data source: Gallup World Poll.

Food security is considered to be a result of political economy and social inclusion. Aligned with that, the period in which there was an outstanding improvement in food security status in Brazil (2004 to 2013) was marked by high investments in social policies, financial growth (reaching a GDP growth of $7.5 \%$ in 2010) and reduction in unemployment 14,15. In the diagram presented by Timmer 6, economic growth and political stability are shown as macro determinants of food security. From this perspective, it can be assumed that the economic stagnation and the subsequent recession played a major role in increasing food insecurity in Brazil. In contrast to the large GDP growth seen in Brazil before the crisis, since 2015 growth rates have been among the worst in the nation's history $(-3.8 \%$ in 2015 and $-3.6 \%$ in 2016) 15. In addition, this economic crisis has happened in a setting of political 
Table 4

Adjusted odds ratios (OR) for food insecurity during the crisis (2014 to 2017) in Brazil.

\begin{tabular}{|c|c|c|}
\hline Variables & OR & $95 \% \mathrm{Cl}$ \\
\hline \multicolumn{3}{|c|}{ Household income per capita (minimum wage) } \\
\hline \multicolumn{3}{|l|}{ More than 1 (reference) } \\
\hline $1 / 2$ to 1 & $2.01 *$ & $1.63-2.49$ \\
\hline $1 / 4$ to $1 / 2$ & $3.72 *$ & $2.91-4.74$ \\
\hline No income to $1 / 4$ & $6.42 *$ & $4.71-8.75$ \\
\hline \multicolumn{3}{|l|}{ Job climate } \\
\hline \multicolumn{3}{|l|}{ High (reference) } \\
\hline Moderate & $1.37 * *$ & $1.01-1.87$ \\
\hline Low & 1.84 * & $1.37-2.46$ \\
\hline \multicolumn{3}{|c|}{ Perception of the political stability } \\
\hline \multicolumn{3}{|l|}{ Very stable (reference) } \\
\hline Somehow stable & 0.83 & $0.59-1.17$ \\
\hline Not stable at all & 0.87 & $0.63-1.21$ \\
\hline \multicolumn{3}{|l|}{ Social support } \\
\hline \multicolumn{3}{|l|}{ High (reference) } \\
\hline Moderate & 1.51 * & $1.24-1.83$ \\
\hline Low & $2.37 * *$ & $1.44-3.89$ \\
\hline \multicolumn{3}{|l|}{ Household size } \\
\hline \multicolumn{3}{|l|}{1 to 3 (reference) } \\
\hline 4 to 5 & 0.95 & $0.79-1.14$ \\
\hline 6 or more & $1.35 * *$ & $1.00-1.83$ \\
\hline \multicolumn{3}{|l|}{ Age } \\
\hline \multicolumn{3}{|c|}{ Youth (15 to 29 years) (reference) } \\
\hline Adult (30 to 59 years) & 0.94 & $0,78-1.13$ \\
\hline Elderly (60 years or more) & $0.63 *$ & $0.48-0.84$ \\
\hline \multicolumn{3}{|l|}{ Educational level } \\
\hline \multicolumn{3}{|c|}{ College/University (reference) } \\
\hline Secondary/High school & $1.58 * *$ & $1.11-2.24$ \\
\hline Elementary or less & 2.24 * & $1.55-3.24$ \\
\hline \multicolumn{3}{|l|}{ Gender } \\
\hline \multicolumn{3}{|l|}{ Men (reference) } \\
\hline Women & 0.90 & $0.77-1.06$ \\
\hline
\end{tabular}

95\%Cl: 95\% confidence interval.

Source: Gallup World Poll.

* $\mathrm{p} \leq 0.001$;

** $p \leq 0.05$.

instability in Brazil, marked by a presidential impeachment in 2016 26,27. Thus, it can be assumed that the critical situation of both macro determinants (political stability and economic growth) has contributed synergistically to the deterioration of food security in Brazil from 2015 to 2017.

The distribution of the sample by household income per capita presented larger variations from 2004 to 2017 . The percentage of people living in the lowest strata rose greatly from 2013 (8\%) to 2017 (17\%), while the highest strata decreased almost by half from 2013 (47\%) to 2017 (26\%). The results also showed a higher increase of severe food insecurity among the poorest strata. In contrast, the increase in mild food insecurity was greater among the wealthiest strata. This corroborates previous observations, indicating that political and financial crisis disproportionately affect people's food security status based on their income 2,21,24,32,34.

Out of the socioeconomic variables tested, household income per capita showed the strongest association with food security status; people living with no income to $1 / 4$ minimum wage were six 
times more likely to be food insecure than those living with more than one minimum wage. The association between food security and income is well documented 5,20,21,24,34 and for this reason, Brazil has implemented several food security policies aimed to improve food access by the poor. For example: the Bolsa Família, which is considered the largest conditional cash transfer program in the world and covered a quarter of the Brazilian population in 2012; the Food Acquisition Program (PAA) that improves the income of smallholder farmers; and the Popular Restaurants that provide safe and nutritious meal at an affordable price (usually less than USD 1) 9,10,11. However, these programs have been weakened during the crisis, many Popular Restaurants were closed down, the PAA is suffering from a large budget constraint, and the cash transfer program is having difficulty adjusting to rising inflation and unemployment 26,28,30,31. Thus, our findings indicate that the protective factor of a welldeveloped food security policy environment, once compromised by severe austerity measures, may be insufficient to protect the Right to Food of the poor at times of economic decline.

After income, social support and educational level were the variables most associated with food security. As the impact of social support on food security access has only recently been investigated, our findings give support to its importance. People with low social support were two times more likely to be food insecure. This was expected, as Miller 38 demonstrated the association between functional and structural social support and food security in a study involving 107 countries. This author found that social support improves food security by facilitating the loan of money or food in case of shocks, assisting in the production and preparation of food, and also in forming connections to find employment ${ }^{38}$. According to Silva \& Harpham ${ }^{39}$, mothers receiving greater social support have children (1 year old) with better nutritional status. These findings highlight the protective influence of social support and the importance of the availability of relatives and or friends. This is an area of research that could be used to inform the design of public health and social policies that may highlight the benefit of service delivery using group-based modalities that bring together community members with less socially active demographic groups in a way that provides opportunities for social interaction as a spin-off benefit 40 .

Many studies also showed that people with low levels of education have a higher risk of being food insecure, which is explained by its association with income 5,41. Large family size, which is more common among the poor and low educated, was shown to be associated with food insecurity 5,18,22. In our study, the risk of being food insecure did not differ among households with 1 to 5 residents but households with more than five residents were $35 \%$ more likely to be food insecure. Job climate was also significantly associated with food security status. People with low expectations of job opportunities were two times more likely to be food insecure. As employment generates income, the relationship between job climate and food security status is predictable. The opposite effect was found for increased age, as those over 60 had a protective effect for food security in Brazil with the elderly being $37 \%$ less likely to be food insecure. These findings may be partly explained by a previous study conducted in Brazil in 2008, which showed that in half of the households, older people's income (mainly coming in after retirement) represented the majority of the household earnings 41 . This suggests that older people contributes to the economic stability and food security status of the household 41 .

The causal mechanisms of the association between food insecurity and poverty, lack of social support, low education, low job climate and large household size found in this study can be seen in both directions 1 . In other words, these socioeconomic determinants can also result from food insecurity. For example, a poor diet comprises children's learning ability, and a lower level of education leads to poor job opportunities, lower income and larger household size, which reduces financial access to food. In addition, food insecurity leads to lower productivity, which affects the performance of people at work and can result in the loss of a job 1. Lack of social support can be the cause and consequence of depression and poor mental health, which also compromises people's productivity and learning ability, resulting in lower level of education, lower income and larger household size, and thus greater risk of food insecurity $1,39,40$.

This study has limitations due to the use of secondary data from two different sources to cover the period before (PNAD data) and during the crisis (GWP data) in Brazil. However, both data sources, PNAD and GWP, applied a similar sampling method to ensure national representativeness and, to minimize bias, their data were analyzed separately. In addition, the results of the significant association between food security and income in a dose-response manner (Table 3) consistent across 
all years analyzed show the external validity of these data. The analyses were limited to variables available in the PNAD and GWP and, due to the self-reported nature of the data, reporting bias may be an issue. Moreover, the sample did not cover homeless and institutionalized people, who may be among the most vulnerable groups during economic downturns. This research would benefit from the inclusion of more social variables, such as ethnicity, and demographic variables addressing area of residence (urban and rural) and the Brazilian regions separately. However, GWP did not assess ethnicity, and the methodology for classifying rural and urban areas differs greatly between PNAD and the GWP. Although PNAD provides representative data for each Brazilian region, GWP data are only nationally representative.

In addition to these factors, it was decided that data from 2014 would not be included in this study, the first year of the crisis, since in this year, the GWP applied the Food Insecurity Experience Scale (FIES) instead of the EBIA-8 to measure food security status in Brazil. These scales present differences in their thresholds for moderate and severe food insecurity, as well as in the order of the questions and time of reference ( 3 months versus 12 months prior to the interview); and FIES is based on an individual level while EBIA-8 is based on a household level. Finally, as this is a cross-sectional study, it is not possible to infer causality, but only associations between the variables. Thus, further research could look into the differences between rural and urban areas in this context of economic downturn, or even apply a longitudinal design for a deeper comprehension of the impacts of financial and political shocks on food security.

Despite of its limitations, this study contributes to the discussion on the level and extent of decline in food security that can be generated by economic and political instability even in countries where there is a strong social policy framework. Furthermore, the Brazilian legal framework for food security establishes the need for monitoring food security status to evaluate the impact of public policies 12 , so this study also attends this nationally recognized demand. In addition to being a legislative issue in Brazil, regular food security measurements are important for the country due to the biological, social and economic consequences of food insecurity, which are widely explored in the literature 42 .

\section{Conclusion}

As shown in this study, a great deterioration of food security status was found in Brazil during the current financial and political crisis (2015 to 2017), severely affecting the poorest strata. Low household income per capita was highly associated with food insecurity, increasing in six times the chances of being food insecure among those living with $1 / 4$ minimum wage or less. Low educational level, social support and job climate (poor perception of job opportunities and of the economic situation) were also negatively associated with food security, increasing in 2 times the chances of being food insecure.

Overall, although Brazil achieved widely recognized improvements in food security between 2004 and 2013, the crisis has strongly affected Brazilians, with a great increase in severe food insecurity. Even though the current literature refers to a budgetary decline in food security programs, they likely persist because of the previously achieved legislation. From a policy perspective, these findings highlight the necessity for emergency public policies to stop the deterioration in food security in Brazil and guarantee the access to food, especially for the most vulnerable. Furthermore, this research indicates that these policies should pay particular attention to enhancing income generation, improving access to education and fostering social support in order to promote and protect food security. 


\section{Contributors}

L. R. M. Sousa contributed to the development of the project, data analysis, interpretation of the results and writing of the article. A. M. Segall-Corrêa and A. Saint Ville contributed to the interpretation of the results, editing and review of the article. H. Melgar-Quiñonez supervised the development of the study and contributed to the development of the project, interpretation of the results and review of the article.

\section{Additional informations}

ORCID: Luna Rezende Machado de Sousa (00000002-1181-8356); Ana Maria Segall-Corrêa (00000003-0140-064X); Arlette Saint Ville (0000-00018951-8188); Hugo Melgar-Quiñonez (0000-00017014-8260)

\section{References}

1. Pérez-Escamilla R, Shamah-Levy T, Candel J. Food security governance in Latin America: principles and the way forward. Glob Food Sec 2017; 14:68-72.

2. Food and Agriculture Organization of the United Nations; Pan American Health Organization. Panorama of food and nutritional security in Latin America and the Caribbean. Santiago de Chile: Food and Agriculture Organization of the United Nations/Pan American Health Organization; 2017.

3. Devereux S. Social protection for enhanced food security in sub-Saharan Africa. Food Policy 2016; 60:52-62.

4. Brinkman HJ, de Pee S, Sanogo I, Subran L, Bloem MW. High food prices and the global financial crisis have reduced access to nutritious food and worsened nutritional status and health. J Nutr 2009; 140:153S-61S.

5. Alves Bezerra T, Alves de Olinda R, Figueroa Pedraza D. Insegurança alimentar no Brasil segundo diferentes cenários sociodemográficos. Ciênc Saúde Colet 2017; 22:637-51.

6. Timmer CP. Food security and economic growth: an Asian perspective. Asia Pac Econ Lit 2005; 19:1-7.

7. Davis O, Geiger BB. Did food insecurity rise across Europe after the 2008 crisis? An analysis across welfare regimes. Soc Policy Soc 2017; 16:343-60.

8. Food and Agriculture Organization of the United Nations; International Fund for Agricultural Development; United Nations Children's Fund; World Food Programme; World Health Organization. The state of food insecurity and nutrition in the world 2017: building resilience for peace and food security. Rome: Food and Agriculture Organization of the United Nations; 2017

\section{Acknowledgments}

The authors thank the Gallup Organization for providing access to the data set from the Gallup World Poll.

9. Kepple AW, Segall-Corrêa AM. Food security monitoring in Brazil and other Latin American countries: support for governance with the participation of civil society. Glob Food Sec 2017; 14:79-86

10. Rocha C. Work in progress: addressing food insecurity in Brazil. In: Caraher M, Coveney J, editors. Food poverty and insecurity: international food inequalities. Cham: Springer; 2016. p. 105-15.

11. Godoy KC, Sávio KEO, Akutsu RC, Gubert $\mathrm{MB}$, Botelho RBA. Perfil e situação de insegurança alimentar dos usuários dos Restaurantes Populares no Brasil. Cad Saúde Pública 2014; 30:1239-49.

12. Chmielewska D, Souza D. The food security policy context in Brazil. Brasília: International Policy Centre for Inclusive Growth; 2011. (Country Study, 22).

13. De Schutter O. Countries tackling hunger with a right to food approach. Significant progress in implementing the right to food at national scale in Africa, Latin America and South Asia. Geneva: United Nations; 2010. (Briefing Note 01, May 2010).

14. Câmara Interministerial de Segurança Alimentar e Nutricional. Balanço das ações do Plano Nacional de Segurança Alimentar e Nutricional - PLANSAN 2012-2015. Brasília: Secretaria Executiva, Câmara Interministerial de Segurança Alimentar e Nutricional; 2013.

15. World Bank. World Development Indicators. http://databank.worldbank.org/data/re ports.aspx? source $=2 \&$ series $=$ NY.GDP.MKTP. KD.ZG\&country=BRA. 
16. Skoufias E, Nakamura S, Gukovas R. Safeguarding against a reversal in social gains during the economic crisis in Brazil. Poverty and inequality monitoring: Latin America and the Caribbean. Washington DC: World Bank Group; 2017.

17. International Food Policy Research Institute. Global Nutrition Report 2016: from promise to impact: ending malnutrition by 2030 . Washington DC: International Food Policy Research Institute; 2016.

18. Segall-Corrêa AM, Marin-Leon L, Helito H, Pérez-Escamilla R, Santos LMP, Paes-Sousa R. Transferência de renda e segurança alimentar no Brasil: análise dos dados nacionais. Rev Nutr 2008; 21 Suppl:39-51.

19. Instituto Brasileiro de Geografia e Estatística. Pesquisa Nacional por Amostra de Domicílios: segurança alimentar 2013. Rio de Janeiro: Instituto Brasileiro de Geografia e Estatística; 2014.

20. Shahraki SH, Amirkhizi F, Amirkhizi B, Hamedi S. Household food insecurity is associated with nutritional status among Iranian children. Ecol Food Nutr 2016; 55:473-90.

21. Vilar-Compte M, Sandoval-Olascoaga S, Bernal-Stuart A, Shimoga S, Vargas-Bustamante A. The impact of the 2008 financial crisis on food security and food expenditures in Mexico: a disproportionate effect on the vulnerable. Public Health Nutr 2015; 18:2934-42.

22. Olayemi AO. Effects of family size on household food security in Osun State, Nigeria. Asian Journal of Agriculture and Rural Development 2012; 2:136-41.

23. Mittal A. The 2008 food price crisis: rethinking food security policies. New York/Geneva: United Nations; 2009. (G-24 Discussion Paper Series, 56).

24. Akter S, Basher SA. The impacts of food price and income shocks on household food security and economic well-being: evidence from rural Bangladesh. Glob Environ Change 2014; 25:150-62.

25. Nandy S, Daoud A, Gordon D. Examining the changing profile of undernutrition in the context of food price rises and greater inequality. Soc Sci Med 2016; 149:153-63.

26. Paula LF, Pires M. Crise e perspectivas para a economia brasileira. Estud Av 2017; 31:125-44.

27. Gimenez DM. Política social e desequilíbrios regionais no Brasil em tempos de crise. Texto para Discussão 2017; (301):1-25.

28. Rossi P, Mello G. Choque recessivo e a maior crise da história: a economia brasileira em marcha à ré. Campinas: Centro de Estudos de Conjuntura e Política Econômica, Instituto de Economia, Universidade Estadual de Campinas; 2017. (Nota do Cecon, 1).

29. Lameiras MAP, Carvalho LM. Nota Técnica - A inflação dos alimentos: uma análise do desempenho recente. Brasília: Instituto de Pesquisa Econômica Aplicada; 2016. (Carta Conjuntura, 31).
30. Silva HNM. A crise no estado do Rio de Janeiro, relações econômicas e políticas. Boletim de Conjuntura 2017; II:29-41.

31. Heling CA, Oliveira ER, Almeida RA, Gabriel AMA, Magalhães AM, Souza AG, et al. Programa de aquisição de alimentos em MS: soberania alimentar, crise e perspectivas de superação. Realização 2017; 4:51-78. http:// ojs.ufgd.edu.br/index.php/realizacao/article/ view/7252.

32. Kavallari A, Fellmann T, Gay SH. Shocks in economic growth $=$ shocking effects for food security? Food Sec 2014; 6:567-83.

33. Timmer CP. Food security, structural transformation, markets and government policy. Asia Pac Policy Stud 2017; 4:4-19.

34. Headey DD. The impact of the global food crisis on self-assessed food security. World Bank Econ Rev 2013; 27:1-27.

35. Food and Agriculture Organization of the United Nations. Methods for estimating comparable rates of food insecurity experienced by adults throughout the world. Rome: Food and Agriculture Organization of the United Nations; 2016.

36. Gallup Inc. Worldwide research. Methodology and codebook. Washington DC: Gallup Inc.; 2017.

37. Interlenghi GS, Reichenheim ME, Segall-Corrêa AM, Pérez-Escamilla R, Moraes CL, SallesCosta R. Suitability of the eight-item version of the Brazilian Household Food Insecurity Measurement Scale to identify risk groups: evidence from a nationwide representative sample. Public Health Nutr 2018; [Epub ahead of print].

38. Miller M. Food security and social support: exploring relationships between social resources and access to adequate food [Masters Thesis]. Montreal: School of Dietetics and Human Nutrition, McGill University; 2015.

39. Silva MJ, Harpham T. Maternal social capital and child nutritional status in four developing countries. Health Place 2007; 13:341-55.

40. Na M, Miller M, Ballard T, Mitchell DC, Hung YW, Melgar-Quiñonez H. Does social support modify the relationship between food insecurity and poor mental health? Evidence from thirty-nine sub-Saharan African countries. Public Health Nutr 2019; 22:874-81.

41. Rosa TEC, Mondini L, Gubert MB, Sato GS, Benício MH. Segurança alimentar em domicílios chefiados por idosos, Brasil. Rev Bras Geriatr Gerontol 2012; 15:69-77.

42. Hadley C, Crooks DL. Coping and the biosocial consequences of food insecurity in the 21st century. Am J Phys Anthropol 2012; 149 Suppl 55:72-94. 


\section{Resumo}

O estudo teve como objetivos descrever as mudanças na segurança alimentar no Brasil antes e durante a mais recente crise financeira e politica do país, além de explorar as associações entre segurança alimentar e fatores socioeconômicos $d u$ rante a crise. Este estudo transversal analisou os dados de duas fontes diferentes: a Pesquisa $\mathrm{Na}$ cional por Amostra de Domicílios de 2004 $(n=112.479), 2009(n=120.910)$ e $2013(n=$ 116.192) e a Pesquisa Mundial Gallup de 2015 $(n=1.004), 2016(n=1.002)$ e $2017(n=1.001)$. O nível de segurança alimentar domiciliar foi medido utilizando uma versão reduzida da Escala Brasileira de Insegurança Alimentar (EBIA), com as primeiras oito perguntas da escala original de 14 itens. Foram realizadas análises descritivas e de regressão logística para avaliar as mudanças na segurança alimentar e a associação com fatores socioeconômicos. Os resultados sugerem que durante a crise, o percentual de domicílios com segurança alimentar diminuiu em um terço (de 76\% em 2013 para 49\% em 2017), enquanto a insegurança alimentar grave triplicou (de 4\% em 2013 para 12\% em 2017). Antes da crise (2013), 44\% dos domicílios apresentavam segurança alimentar, mas até 2017 essa proporção havia diminuído para 26\%. A renda per capita domiciliar mostrou forte associação com a segurança alimentar, aumentando em seis vezes a probabilidade de insegurança alimentar entre os mais pobres. Aqueles que relatavam piores niveis de emprego, apoio social e escolaridade tiveram duas vezes mais probabilidade de sofrer de insegurança alimentar. Apesar de melhoras significativas entre 2004 e 2013, os achados indicam que durante a crise, o Brasil sofreu uma piora grave na segurança alimentar, reforçando a necessidade de politicas emergenciais para proteger e garantir o acesso à alimentação para os mais vulneráveis.

Segurança Alimentar e Nutricional; Epidemiologia Nutricional; Fatores Socioeconômicos

\section{Resumen}

El objetivo de este estudio es describir los cambios en el estado de la seguridad alimentaria en Brasil antes y durante su más reciente crisis politica y financiera, así como también analizar las asociaciones entre seguridad alimentaria y factores socioeconómicos durante la crisis. Este estudio transversal analizó datos de dos fuentes diferentes: la Encuesta Brasileña por Muestra de Domicilios en $2004(n=112.479), 2009(n=120.910)$ y 2013 ( $n=116.192) ; y$ la Encuesta Mundial Gallup en $2015(n=1.004), 2016(n=1.002) y$ 2017 ( $n=1.001)$. El estado de la seguridad alimentaria por hogar se midió mediante una versión acortada de la Escala Brasileña de Inseguridad Alimentaria, que consiste en las 8 primeras preguntas de la escala original con 14-items. Se realizaron análisis descriptivos y por regresión logística para evaluar los cambios en la seguridad alimentaria y su asociación con factores socioeconómicos. Los resultados sugieren que durante la crisis el porcentaje de hogares clasificados como seguros respecto a la alimentación disminuyó en un tercio (del 76\% en 2013 al 49\% en 2017) mientras que la inseguridad alimentaria severa se triplicó (de un 4\% en 2013 al 12\% en 2017). Asimismo, antes de la crisis (2013) un 44\% de los hogares más pobres contaban con seguridad alimentaria, pero en 2017 este número disminuyó al 26\%. Los ingresos per cápita por hogar estuvieron fuertemente asociados con la seguridad alimentaria, incrementando seis veces más las posibilidades de sufrir inseguridad alimentaria entre los estratos más pobres. Aquellos que informaron de una baja estabilidad laboral, apoyo social o nivel educacional fueron dos veces más propensos de sufrir inseguridad alimentaria. A pesar de las mejoras significativas entre $2004 y$ 2013, los resultados indican que Brasil durante la crisis sufrió un gran deterioro de la seguridad alimentaria, resaltando la necesidad de politicas de emergencia para proteger y garantizar el acceso a la comida de los más vulnerables.

Seguridad Alimentaria y Nutricional; Epidemiología Nutricional; Factores Socioeconómicos
Submitted on $05 /$ May/2018

Final version resubmitted on 13/Feb/2019

Approved on 15/Feb/2019 